Article

\title{
Development of Legumes After Reseeding in Permanent Grassland, as Affected by Nitrogen Fertilizer Applications
}

\author{
Karin Weggler ${ }^{1, *}$, Ulrich Thumm ${ }^{2}$ and Martin Elsaesser ${ }^{1,2}$ \\ 1 Landwirtschaftliches Zentrum Baden Württemberg (LAZBW); Grünlandwirtschaft und Futterbau, \\ 88326 Aulendorf, Germany \\ 2 University of Hohenheim, Institut für Kulturpflanzenwissenschaften, Fachgebiet Nachwachsende Rohstoffe \\ und Bioenergiepflanzen, 70593 Stuttgart, Germany \\ * Correspondence: Karin.Weggler@lazbw.bwl.de; Tel.: +49-7525-942-358
}

Received: 4 July 2019; Accepted: 16 September 2019; Published: 20 September 2019

\begin{abstract}
Legumes in grassland can increase locally grown protein in fodder while reducing the nitrogen (N)-fertilizer requirements. Although the benefits of forage legumes are known, there was a decline in their use in the past due to inexpensive $\mathrm{N}$-fertilizer, soya products from abroad, and variable legume persistence. In recent years, mounting environmental concern has sparked new interest in legumes. To quantify the effect of legume reseeding and $\mathrm{N}$-application on permanent grassland on crude protein (CP) and dry matter yield (DM), a multifactorial trial was set up. Factors considered were clover species (red clover, white clover), $\mathrm{N}$-application rate $\left(0-170 \mathrm{~kg} \mathrm{~N}^{-1}\right.$ ), N-fertilizer type (mineral-N, organic-N), and cutting management (3,5-cut). Legume percentages were scored, and DM- and CP-yield was measured for three years. Crude-protein gains after legume reseeding were considerable and between 2.5-3.4 after red clover and 0.4-1.7 t CP ha $^{-1} 3$ years ${ }^{-1}$ after white clover-reseeding even when compared to the control-high- $\mathrm{N}$ treatment. Legume percentages were negatively correlated to N-rates down to rates as low as 42 or $85 \mathrm{~kg} \mathrm{~N} \mathrm{ha}^{-1}$ for a three- or five-cut management, respectively. Nitrogen-applications increased the yield (DM, CP) of control plots, whereas for legume-reseeded plots yield remained unchanged or was reduced. Differences due to $\mathrm{N}$-fertilizer type were small or non-existent. Reseeding of clover was shown to be a viable method to increase crude protein in permanent grassland for about three years (red clover) and possibly beyond (white clover).
\end{abstract}

Keywords: legumes; clover; permanent grassland; crude protein; nitrogen-fertilizer; protein-yield

\section{Introduction}

Increases in agricultural output are necessary to feed a growing population, but at the same time, this should be done in ways that do not compromise environmental integrity [1-3]. The widespread use of nitrogen $(\mathrm{N})$ fertilizer has various impacts on the environment and generates a substantial proportion of the Greenhouse gas (GHG) emissions associated with crop production [3-5].

At the same time, current food production is highly N-limited [6]. High agricultural productivity, whether intended for human consumption or animal fodder, is based on a sufficient supply of $\mathrm{N}$ to plants. The high demand for meat and milk products requires large amounts of feedstock, which in intense agricultural systems is dependent on the application of N-fertilizers. Furthermore, high animal productivity, particularly for lactating ruminant animals, can only be sustained with protein-rich feedstock. However, the dependence on genetically modified soya from abroad is not desirable. Forage legumes contain high amounts of readily digestible protein, which could substitute for soya products in livestock fodder. They provide further ecosystem services such as some tolerance to drought due 
to their generally deeper rooting system [7], they are a food source for insects (which is important in biodiversity strategies), and they can reduce the need for $\mathrm{N}$-fertilizer.

Legumes are one of the few plant types that are able to symbiotically fix $\mathrm{N}_{2}$ from the atmosphere and thereby produce more protein with less $\mathrm{N}$-fertilizer input. The amount of symbiotically fixed nitrogen can be considerable but also quite variable and was quoted to be between $8-373 \mathrm{~kg} \mathrm{~N} \mathrm{ha}^{-1}$ year ${ }^{-1}$ in pure stands of red clover (Trifolium pratense L.) (RC) and $10-545 \mathrm{~kg} \mathrm{~N} \mathrm{ha}^{-1} \mathrm{year}^{-1}$ in white clover (Trifolium repens L.) (WC) in above ground tissue [8]. For a mixed sward (legume percentage $40 \%$, DM yield $12 \mathrm{t} \mathrm{ha}^{-1}$ ), the $\mathrm{N}_{2}$ fixation can be estimated to be 132 and $173 \mathrm{~kg} \mathrm{~N} \mathrm{ha}^{-1}$ year $^{-1}$ for $\mathrm{RC}$ and WC, respectively, using their established equations. Also, there is no evidence of significant $\mathrm{N}_{2} \mathrm{O}$ emissions arising from the process of symbiotic $\mathrm{N}_{2}$-fixation $[5,9,10]$. Additionally, they can transfer up to $60 \mathrm{~kg} \mathrm{ha}^{-1}$ year $^{-1}$ of fixed-N from legumes to companion grasses [11-13]. Mixtures of various species, including legumes, were found to be highly productive, so called transgressive overyielding [14], since they can benefit from the complementary uptake of different soil resources.

Despite all their benefits, there has been a net decline in the use of forage legumes since the 1980s in many parts of Europe [15] Currently, grassland-based livestock production of medium to high management intensity depends largely on high yielding grass-dominated stands requiring large inputs of $\mathrm{N}$-fertilizer. Legumes have fallen out of favor because farmers experienced significant fluctuations [15] and found it difficult to maintain a relevant percentage of clover in productive grassland for an extended period of time [16]. Moreover, an abundant supply of concentrated feed enables high livestock stocking rates, which result in relevant amounts of $\mathrm{N}$ in farmyard manures, which likely impede high percentages of legumes in swards.

Since there is a heightened awareness recently that legume-based grassland or grazing systems have the ability to reduce environmental problems [15], a number of studies have been conducted to estimate the yield potential in dry matter production [14] and total N-uptake [17] of grass legume mixtures. With legume contents of 50-70\%, it has been found that sward DM-yield was higher compared to the best performing monoculture [14], and significant gains in N-uptake could be measured with legume percentages as low as 30\% [17]. However, these trials were conducted on newly established, short-term pastures. Legume percentages in permanent grassland need to be increased by alternative methods of grassland renovation and should be sustained over an extended period of time.

Reseeding of legumes in an existing sward was shown to be a promising method to increase the legume percentage $[18,19]$. Legumes used were RC, usually grown in short term stands, and WC, typically grown with a companion grass for grazing [20,21]. However, even when pre-seeding management, soil moisture, and temperature could be considered appropriate [21], reseeding of legumes was not successful in every case [18]. It was suspected that the level of nitrogen fertilization did have a negative impact on legume establishment since grasses are highly competitive for soil mineral-N [22]. A negative impact of high $\mathrm{N}$-fertilizer rates on white clover growth has been reported previously [23], whereas low $\mathrm{N}$-application rates $\left(<100 \mathrm{~kg} \mathrm{~N} \mathrm{ha}^{-1}\right)$ appeared to not have affected white clovers efficiency to fix $\mathrm{N}_{2}$ [24].

Nevertheless, there is little information, which $\mathrm{N}$-application rate is most favorable to introduce legumes into existing permanent grassland swards by means of reseeding and to sustain legumes over an extended period of time. Our multifactorial trial had three major aims. Firstly, we wanted to assess the impact of different $\mathrm{N}$-application rates $\left(0-170 \mathrm{~kg} \mathrm{~N} \mathrm{ha}^{-1}\right)$ on legume establishment and legume percentage over time. Second, we wanted to quantify the effect of $\mathrm{N}$-application rates on dry matter and protein production in reseeded, mixed swards. Third, we wanted to determine if the type of N-fertilizer, mineral or organic, is of major importance. Since grassland management regionally varies in cutting frequencies, we repeated all relevant legume by $\mathrm{N}$-fertilizer treatments under a threeand five-cut management system. 


\section{Materials and Methods}

\subsection{Trial Site}

The trial was established in 2014 on permanent grassland in Aulendorf (South Germany, $590 \mathrm{~m}$ asl; GPS data: $47^{\circ} 57^{\prime} 35.8^{\prime \prime} \mathrm{N}, 9^{\circ} 38^{\prime} 04.4^{\prime \prime}$ E) that contained $90 \%$ grass, $6 \%$ herbs, and $4 \%$ white clover. The dry matter (DM) percentages of plant groups were evaluated according to the method by Klapp and Stählin [25]. The most common grasses at the start of the experiment were Phleum pratense (68\%), Lolium perenne (12\%), Lolium hybridum ( $8 \%$ ) and common herbs were Taraxacum officinale (3\%) and Plantago lanceolata (3\%). The soil is a loamy sand to sandy loam with a $\mathrm{pH}$ of 6.8 (Luvisol over moraine clay). Plant available soil nutrient concentrations were determined in 2014 as $20.3 \mathrm{mg} \mathrm{P}_{2} \mathrm{O}_{5} 100 \mathrm{~g}^{-1}$

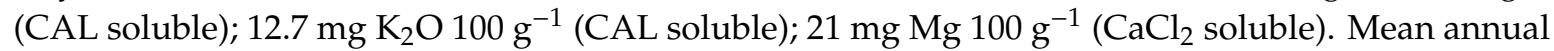
temperature and sum of annual rainfall during the trial period, from 2015 to 2017, are listed in Table 1. The climate is classified as Cfb after Köppen \& Geiger [26].

Table 1. Mean annual rainfall and mean annual temperature at the trial site ${ }^{1}$.

\begin{tabular}{cccccc}
\hline Attribute & $\mathbf{1 9 6 0 - 1 9 9 0}$ & $\mathbf{2 0 1 4}$ & $\mathbf{2 0 1 5}$ & $\mathbf{2 0 1 6}$ & $\mathbf{2 0 1 7}$ \\
\hline Annual rainfall $(\mathrm{mm})$ & 902 & 795 & 923 & 1114 & 1072 \\
Mean annual Temp $\left({ }^{\circ} \mathrm{C}\right)$ & 7.6 & 9.7 & 9.6 & 9.3 & 9.2 \\
\hline \multicolumn{7}{c}{ Weather station: Bad Schussenried. }
\end{tabular}

\subsection{Trial}

The multifactorial trial included 27 treatments with 12 treatments in the three-cut management and 15 treatments in the five-cut management (Table 2). Treatments in the three-cut management included $\mathrm{N}$-application rates of 42.5 and $85 \mathrm{~kg} \mathrm{~N} \mathrm{ha}^{-1}$ with the highest rate being applied as mineral and as organic fertilizer (slurry). Treatments in the five-cut management included N-application rates of 85 and $170 \mathrm{~kg} \mathrm{~N} \mathrm{ha}^{-1}$ with the medium rates being applied as mineral- and as organic fertilizer (slurry) and the high rate as mineral and mineral plus organic fertilizer (slurry). The N-fertilizer treatments were applied to three legume treatments (Control-no reseeding, RC-reseeding, WC-reseeding), which resulted in 27 treatments altogether. Treatments were randomized in an incomplete, multifactorial split-plot design with three replicates plots $(1.25$ by $8 \mathrm{~m})$.

Table 2. Factorial treatment combinations applied in the trial. Factors considered were (a) reseeded legumes, (b) cutting frequency, (c) annual nitrogen (N)-fertilizer-rate, and (d) nitrogen (N)-fertilizer-type. The factorial combinations $(b, c, d)$ were applied to each legume-treatment, listed in the same line.

\begin{tabular}{cccccc}
\hline Legume & $\begin{array}{c}\text { Cutting } \\
\text { Frequency }\end{array}$ & $\begin{array}{c}\text { Total N-Rate } \\
(\mathbf{k g ~ h a - 1 )}\end{array}$ & $\begin{array}{c}\text { N-Fertilizer } \\
\text { Type }\end{array}$ & Label & $\begin{array}{c}\text { N Applied } \\
\text { Prior Cut }\end{array}$ \\
\hline Contr./RC/WC & 3 & 0 & Mineral & 0 & \\
Contr./RC/WC & 3 & 42 & Mineral & 42 & 1 \\
Contr./RC/WC & 3 & 85 & Mineral & 85 & 1,2 \\
Contr./RC/WC & 3 & 85 & Slurry & $85 \mathrm{~s}$ & 1,2 \\
Contr./RC/WC & 5 & 0 & Mineral & 0 & \\
Contr./RC/WC & 5 & 85 & Mineral & 85 & 1,3 \\
Contr./RC/WC & 5 & 85 & Slurry & $85 \mathrm{~s}$ & 1,2 \\
Contr./RC/WC & 5 & 170 & Mineral & 170 & $1,2,3$ \\
Contr./RC/WC & 5 & 170 & Slu. -Min & $170 \mathrm{~s}$ & $1,2,3$ \\
\hline
\end{tabular}

Contr.-no legumes; RC-Trifolium pratense L.; WC-Trifolium repens L.; "I" denotes "or". 


\subsection{Fertilizer}

Mineral or organic $\mathrm{N}$-fertilizer was applied prior cut 1,2, or 3 as listed in Table 2 with a maximum of $42 \mathrm{~kg} \mathrm{~N} \mathrm{ha}^{-1}$ per application. The organic fertilizer was cattle slurry, which contained on average $0.21 \%$ of total $\mathrm{N}$ and was applied at a rate of $2 \times 20 \mathrm{~m}^{3} \mathrm{ha}^{-1}$ with band spreading. Calcium ammonium nitrate was used as mineral nitrogen fertilizer. Phosphorus $(\mathrm{P})$ was applied as base fertilizer at a rate of 70 or $110 \mathrm{~kg} \mathrm{P}_{2} \mathrm{O}_{5} \mathrm{ha}^{-1}$ for the three- and five-cut management, respectively and potassium (K) was applied at a rate of 220 or $330 \mathrm{~kg} \mathrm{~K}_{2} \mathrm{O} \mathrm{ha}{ }^{-1}$ for the three- and five-cut management, respectively. Humigras (TiMacAgro, Troisdorf, Germany) was used as P and potassium-Sulphat (Kalisop, K+S Kali, Kassel, Germany) as K-fertilizer. For organic fertilizer treatments, the amount of P and K added with the slurry was subtracted from the mineral $\mathrm{P}$ and $\mathrm{K}$ base fertilizer rate.

\subsection{Seeding}

The grassland was opened up with a harrow one week prior reseeding in May 2014. Red clover was reseeded using a slot seeder, at a rate of $20 \mathrm{~kg} \mathrm{ha}^{-1}$ with an equal ratio of the two varieties Merula (Feldsaaten Freudenberger) and Milvus (DSV). White clover was reseeded at a rate of $10 \mathrm{~kg} \mathrm{ha}^{-1}$ with the varieties Merlyn (Feldsaaten Freudenberger) and Riesling (DLF B.V.).

\subsection{Measurements}

The DM percentages of legumes, grasses, and herbs were scored prior to each cut according to the method by Klapp and Stählin [25]. Plots were harvested using a plot harvester and fresh weight was determined. Cutting height was $5 \mathrm{~cm}$. Subsamples from each plot were dried at $60^{\circ} \mathrm{C}$, weighed, and dry matter production for each cut was calculated accordingly. Those subsamples were ground and analyzed for crude protein content (CP) by near infrared spectroskopie NIRS [27].

\subsection{Statistical Analysis}

Statistical analysis was conducted using R (R development Core Team 2016, Vienna, Austria). The legume percentages were analyzed separately for the three- and five-cut management using a linear mixed effects model, lmer function in the lme4 package. Analyses were conducted separately for each year. Clover, nitrogen rate, and time of cutting (1-3 or 1-5) were determined to be fixed effects, and replicate was determined to be a variable effect. Dry matter and protein yield were analyzed using analysis of variance (aov) with the three years being analyzed separately. Comparisons of means were calculated using the lsmeans function with "Tukey" adjustments. Models and correlation-coefficients to describe the relation between legume percentage and $\mathrm{CP}$-yield were calculated using the $\mathrm{lm}$ function in R.

\section{Results}

\subsection{Legume Content in the Grassland}

The percentages of legumes prior to each cut as affected by legume reseeding and fertilizer treatments for up to 3.5 years after reseeding are shown in (Figure 1). Red clover percentage under a three-cut management reached levels up to $80 \%$ but was generally around $70 \%$ and declined slightly over the three years. In contrary, WC did not establish well under a three-cut management and reached proportions of only about $12 \%$ during the 3.5 years after reseeding. Under a five-cut management, legume reseeding enhanced the legume proportion of RC up to $80 \%$ but generally around $75 \%$ and in WC plots up to $50 \%$ and generally around $40 \%$ in the $0 \mathrm{~N}$ treatments. 

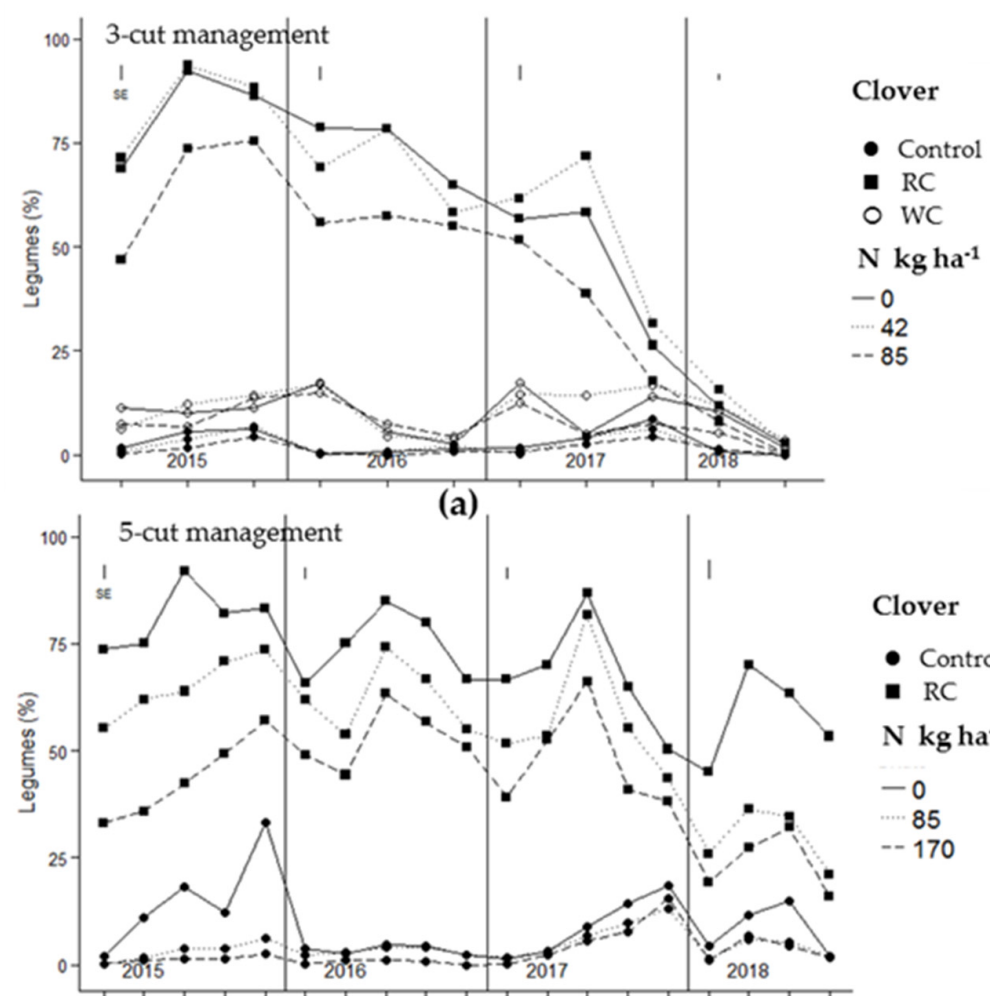

\section{Clover}

- Control

- RC

N kg ha' ${ }^{-1}$

$-0$

-
--175
--170

$--170$

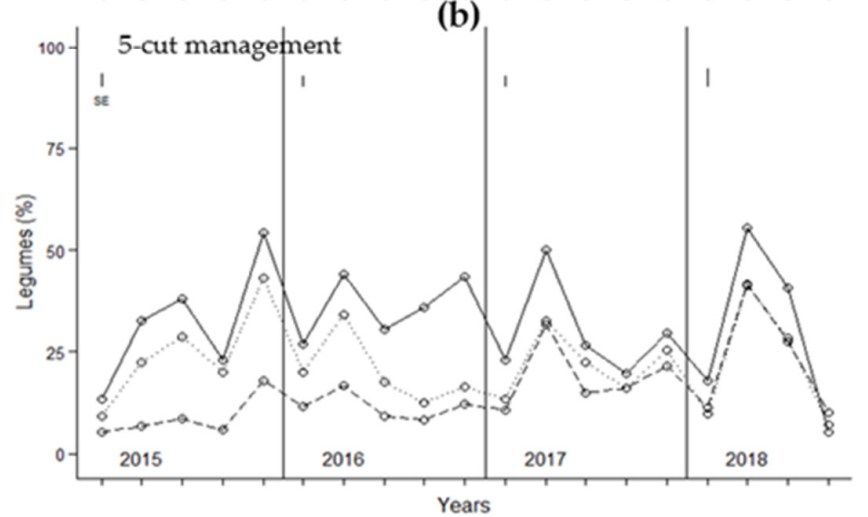

Clover

O WC

N kg ha'

$-0$

-... 85

(c)

Figure 1. Effect of nitrogen (N) fertilizer application rates on legume percentage in red clover (RC) or white clover (WC) reseeded plots compared to the control plots (Control) under a (a) three-cut management or (b) and (c) under a five-cut management.

\subsubsection{Nitrogen Rates}

Legume proportion was significantly influenced by $\mathrm{N}$-application rates (Figure 1). Increasing fertilizer applications decreased the percentage of legumes in all harvests and for both legume species. Proportions of RC declined from generally around $75 \%(0 \mathrm{~N})$ to generally around $40-50 \%$ with $\mathrm{N}$-application rates of $170 \mathrm{~kg} \mathrm{ha}^{-1}$. Similarly, the percentage of WC declined from around $40 \%(0 \mathrm{~N})$ to around $6-12 \%$ with the highest $\mathrm{N}$-rate. The decrease in legume percentage was positively correlated with $\mathrm{N}$-fertilizer rate and was significant in all years, both legume species and both management options. The only exception was WC under the three-cut management, where legume percentage was already low due the unsuitable management option for WC and was not further reduced by $\mathrm{N}$-applications. The other exception was RC at low N-rates of $42 \mathrm{~kg} \mathrm{~N} \mathrm{ha}^{-1}$ (three-cut management), in which no legume decline compared to the RC-0N treatment was observed. 


\subsubsection{Legume Development Over Time}

Legume proportions remained elevated for about three years after RC reseeding and up to the end of the trial (3.5 years) after WC reseeding (Figure 1). Under a three-cut management RC declined at the end of year 3 , and a further decline to proportions below $5 \%$ was measurable in year 4 . Under a five-cut management, RC constituted a significant proportion of the sward up to and including year 3 but also declined strongly in year 4 . Only in the $0 \mathrm{~N}$ treatment did the RC percentage remained around $50 \%$ in year 4 . In contrast, the WC proportion remained on an elevated level during the whole period of the trial.

\subsubsection{Nitrogen Fertilizer Type}

The influence of $\mathrm{N}$-fertilizer type, mineral or slurry fertilizer, on legume percentage in the sward is shown in Figure 2 for the $\mathrm{N}$-fertilizer rate of $85 \mathrm{~kg} \mathrm{~N} \mathrm{ha}^{-1}$. Nitrogen fertilizer type had an effect on legume proportions only in the first year after reseeding for RC but not for WC. For RC, the effect was dependent on the cutting management, with RC-percentage being decreased in the three-cut and enhanced in the five-cut management, due to slurry in comparison to mineral- $\mathrm{N}$-application. In year 2 and 3 after reseeding, no difference due to $\mathrm{N}$-fertilizer type was measurable.
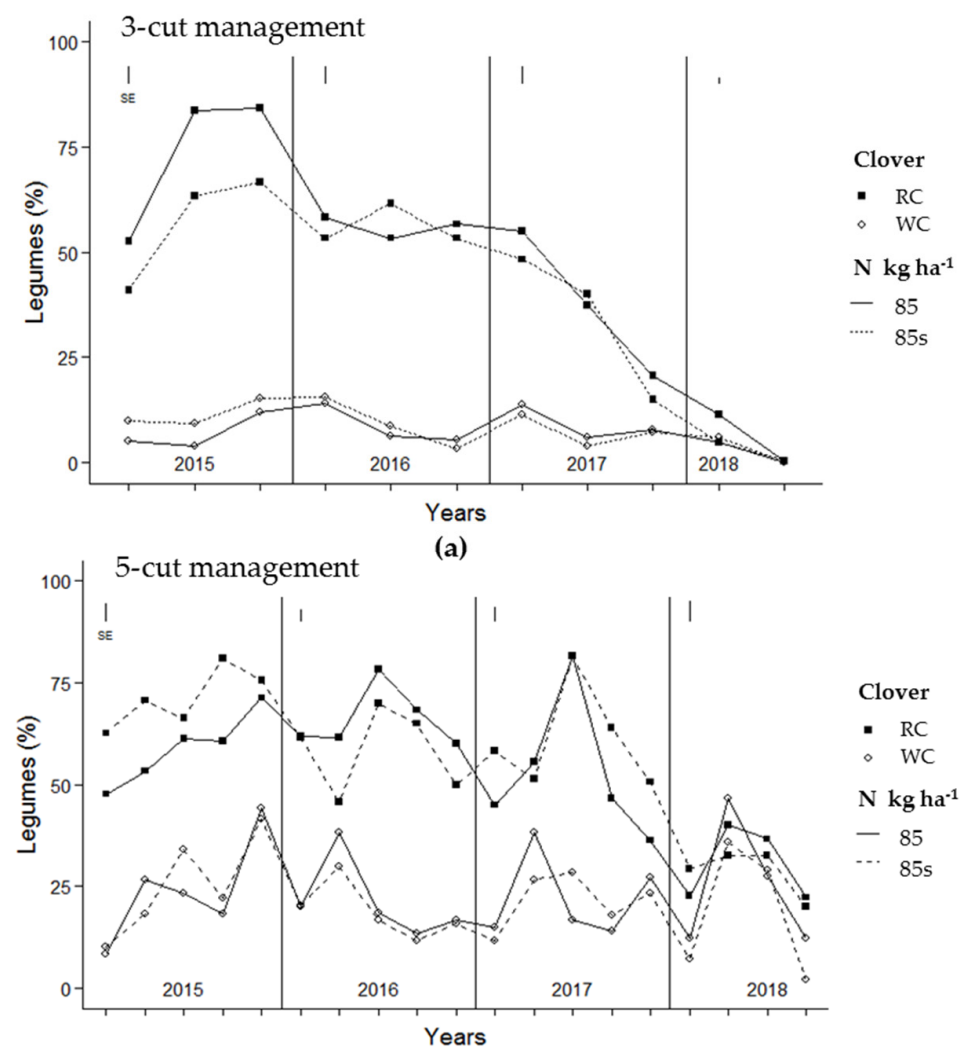

(b)

Figure 2. Effect of slurry- or mineral-N fertilizer applications on the percentage of legumes under a (a) three-cut or (b) five-cut management. ( 85 denotes $85 \mathrm{~kg} \mathrm{~N} \mathrm{ha}^{-1}$ as mineral fertilizer, $85 \mathrm{~s}$ denotes $85 \mathrm{~kg} \mathrm{~N} \mathrm{ha}^{-1}$ as slurry-N).

\subsection{Dry Matter and Crude Protein Yield}

\subsubsection{The Effect of Legumes}

The dry matter (DM) and crude protein (CP) yield as influenced by legume reseeding and $\mathrm{N}$-application rate under a three- and five-cut management are shown in Figures 3 and 4. 


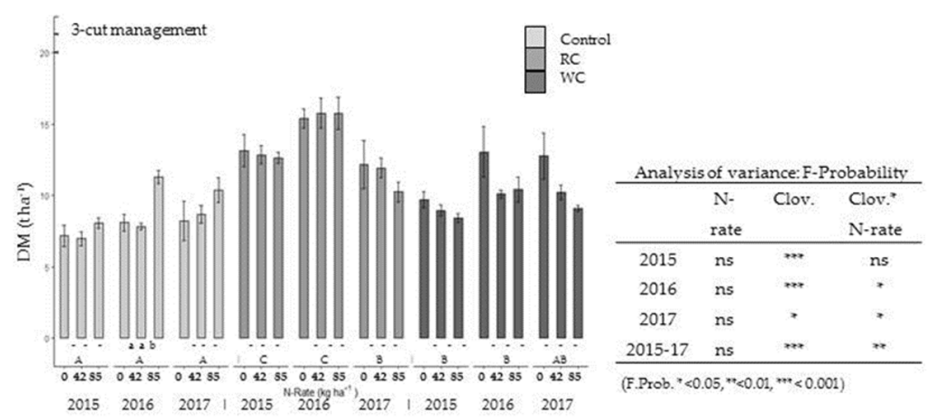

(a)

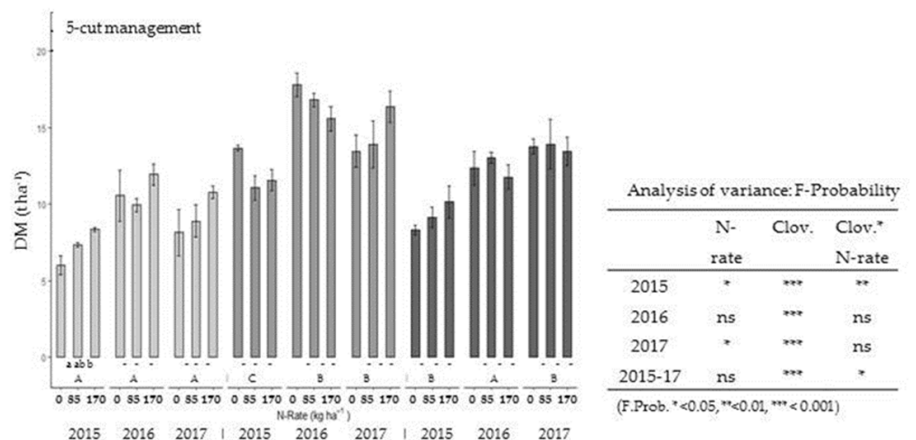

(b)

Figure 3. Effect of legume-reseeding and mineral-N-fertilizer-rate $\left(\mathrm{kg} \mathrm{N} \mathrm{ha}^{-1}\right)$ on dry matter yield (DM) in the three years after reseeding under (a) a three-cut management or (b) a five-cut management (standard error is shown in the graph).

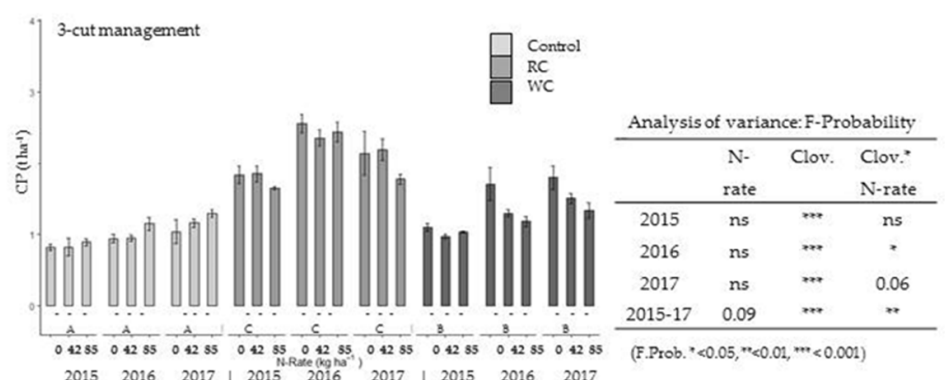

(a)

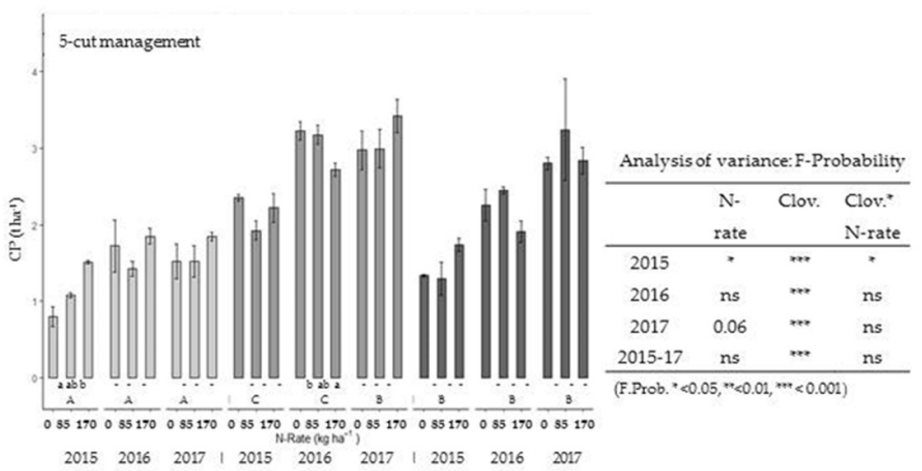

(b)

Figure 4. Effect of legume-reseeding and mineral-N-fertilizer-rate $\left(\mathrm{kg} \mathrm{N} \mathrm{ha}^{-1}\right)$ on crude protein yield $(\mathrm{CP})$ in the three years after reseeding under (a) a three-cut management or (b) a five-cut management (standard error is shown in the graph). 
Dry matter and protein yields were significantly increased due to legume reseeding, when compared to the control treatment, in all three years after reseeding. Dry matter and protein yield were highest in RC reseeded plots and intermediate in WC reseeded plots. On average for the three years, the dry matter harvest for the control treatment was $7.8 \mathrm{tha}^{-1}$ compared to 13.6 and $11.9 \mathrm{t} \mathrm{ha}^{-1}$ for RC and WC reseeded plots under a three-cut management, all treatments without $\mathrm{N}$-fertilizer additions. Crude protein yield was also significantly increased due to clover reseeding with a crude protein yield of $1.04 \mathrm{t} \mathrm{CP} \mathrm{ha}^{-1}$ in the control compared to 2.1 and $1.8 \mathrm{t} \mathrm{CP} \mathrm{ha}^{-1}$ for the RC and WC plots, averaged over the three years (without $\mathrm{N}$-fertilizer). The control plus additional $\mathrm{N}$ fertilizer $\left(85 \mathrm{~kg} \mathrm{~N} \mathrm{ha}^{-1}\right)$ yielded on average $9.9 \mathrm{t} \mathrm{DM} \mathrm{ha}^{-1}$ and $1.3 \mathrm{t} \mathrm{CP} \mathrm{ha}^{-1}$ over the three years, which was significantly lower than the yield in clover reseeded plots without additional- $\mathrm{N}$, listed above. Additional $\mathrm{N}$ to clover reseeded plots, did not affect (RC) or decrease (WC) DM- and CP-yield under a three-cut management.

Similarly under a five-cut management the DM-yield of the RC and WC plots (without additional $\mathrm{N})$ was 15 and $11.5 \mathrm{t} \mathrm{DM} \mathrm{ha}^{-1}$, respectively, which was in most cases significantly higher than the yield in the control- $0 \mathrm{~N}$ of $8.3 \mathrm{t} \mathrm{DM} \mathrm{ha}^{-1}$ or the control-170N treatment of $10.4 \mathrm{t} \mathrm{DM} \mathrm{ha}{ }^{-1}$, averaged over the three years. The crude protein yield was even more substantially increased due to clover reseeding, with the control- $0 \mathrm{~N}$ and control-170N yielding on average 1.3 and $1.7 \mathrm{t} \mathrm{CP} \mathrm{ha}{ }^{-1}$, respectively, whereas $\mathrm{RC}$ and WC reseeded plots yielded on average 2.8 and $2.0 \mathrm{tCP} \mathrm{ha}{ }^{-1}$, respectively, without additional $\mathrm{N}$. These DM- and CP-yield increases due to legume reseeding were measurable in all three years.

\subsubsection{The Effect of $\mathrm{N}$-fertilizer Rate}

Nitrogen fertilizer applied to control treatments significantly increased DM and CP yield in all years and both the three- and five-cut management system (Figures 3 and 4). Nitrogen fertilizer applied to $\mathrm{RC}$ reseeded plots most often did not increase nor decrease dry matter or protein yield. There were two exceptions. In the third year in RC plots under a three-cut management, dry matter and crude protein yield tended to decline with increasing $\mathrm{N}$-application rates. Conversely, in the RC plots in the third year under a five-cut management, the DM and crude protein yield tended to increase with increasing N-rates.

For WC reseeded plots the effect of $\mathrm{N}$-application rates was strongly dependent on cutting regime (Figures 3 and 4). Under a three-cut management, additional $\mathrm{N}$-fertilizer application decreased dry matter and protein yield. This effect was obvious particularly in years 2 and 3, but a similar tendency was obvious already in year 1 after reseeding. $\mathrm{N}$-fertilizer applied to WC under a five-cut management did not increase nor decrease yield in year 2 or 3 . The only exception was year 1 after WC reseeding, when additional $\mathrm{N}$-fertilizer tended to increase DM- and CP-yield.

There were some yield variations between the three years (Figures 3 and 4), with DM- and CP-yields being generally lower in 2015 and higher in 2016 and 2017. These variations were somewhat more pronounced under a five-cut than under a three-cut management. The only exception was the DM yield for RC in 2017, which tended to be lower compared to the DM yield in 2016.

\subsubsection{The Effect of $\mathrm{N}$-fertilizer Type}

The effect of N-fertilizer type, mineral or slurry, on DM-yield is shown in Figure 5a,b. In general, there were no significant differences in DM-yield over the three years when nitrogen was applied as slurry compared to mineral fertilizer. Similarly, under a five-cut management there were generally no significant differences in DM yield due to slurry- or mineral-N fertilizer application. 

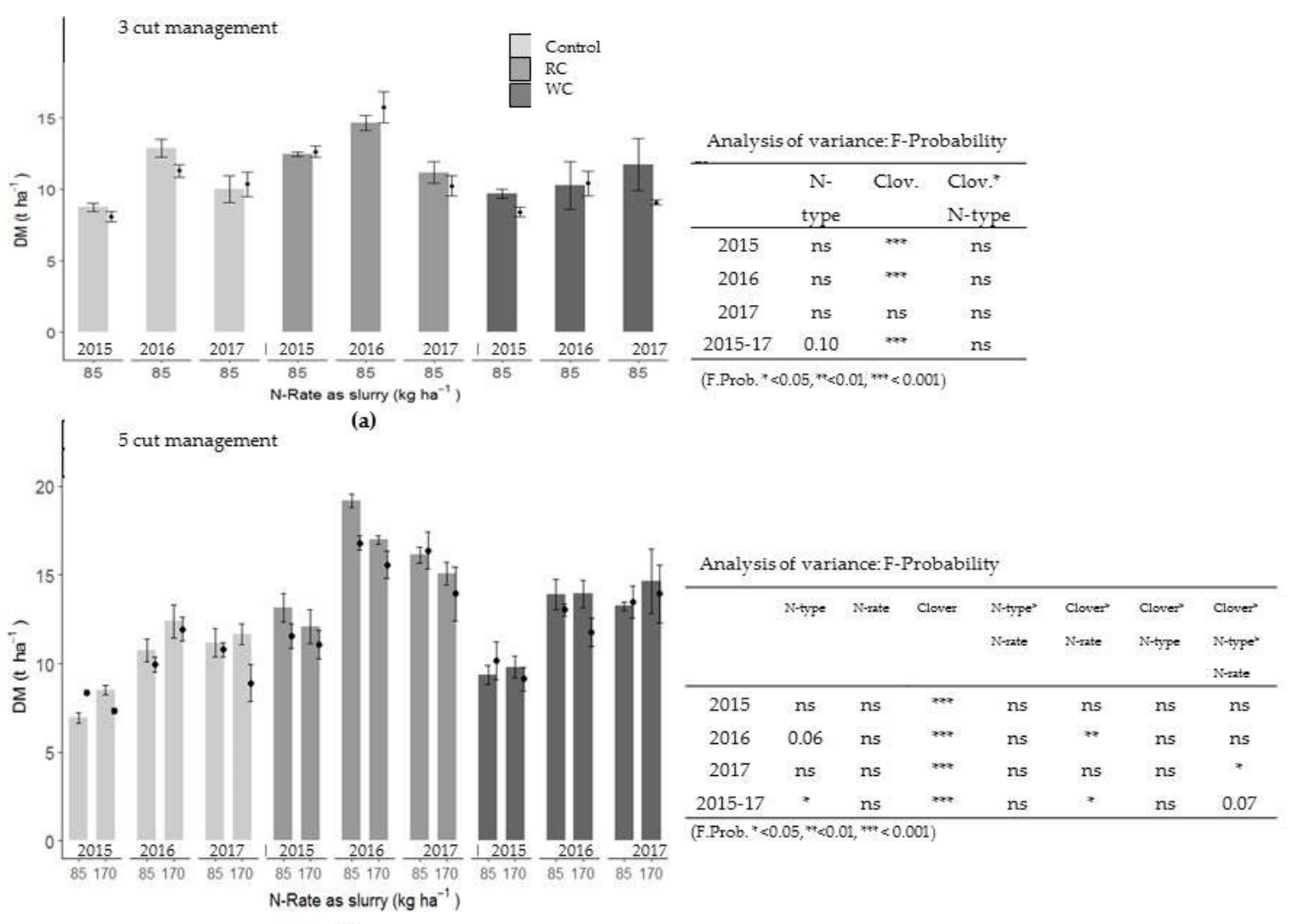

(b)

Figure 5. Effect of fertilizer-type, slurry-N (bars) compared to mineral-N applications (points) on dry matter yield (DM) of control, red clover (RC) or white clover (WC) reseeded plots for the three years after reseeding under (a) a three-cut management or (b) a five-cut management (standard error shown).

\subsubsection{Yield Over Time}

The DM- and CP-yield achieved due to $\mathrm{N}$-fertilizer application (control) compared to yield increases due to clover-reseeding (RC, WC without additional N) are shown in Figure 6a-d for the three-cut and five-cut management. Values summarized over three years are shown in Table 3. Reseeding with RC or WC increased DM- and CP-yield to the same extent and quite often beyond the level achieved with the highest $\mathrm{N}$-fertilizer-rate applied to the control. The DM-yield in WC-reseeded plots $(0 \mathrm{~N})$ was similar to control plots receiving high rates of $\mathrm{N}$, whereas RC-reseeded plots yielded $\mathrm{DM}$ even beyond that level. This was the case in all three years and under both management systems. Similarly, the CP-yield was increased due to $\mathrm{N}$-fertilizer application in the control plots and even further increased in the legume reseeded plots $(0 \mathrm{~N})$. The DM- and (in particular) the CP-yield over time differed between RC and WC reseeded plots, particularly in year 3. For example, the yield in RC plots increase from year 1 to 2 but decreased in year 3, whereas yield in WC plots increased from year 1 to 3. As a result, WC- and RC-reseeded plots yielded similarly in year 3, whereas in years 1 and 2, RC-reseeded plots yielded higher than WC-reseeded plots. 

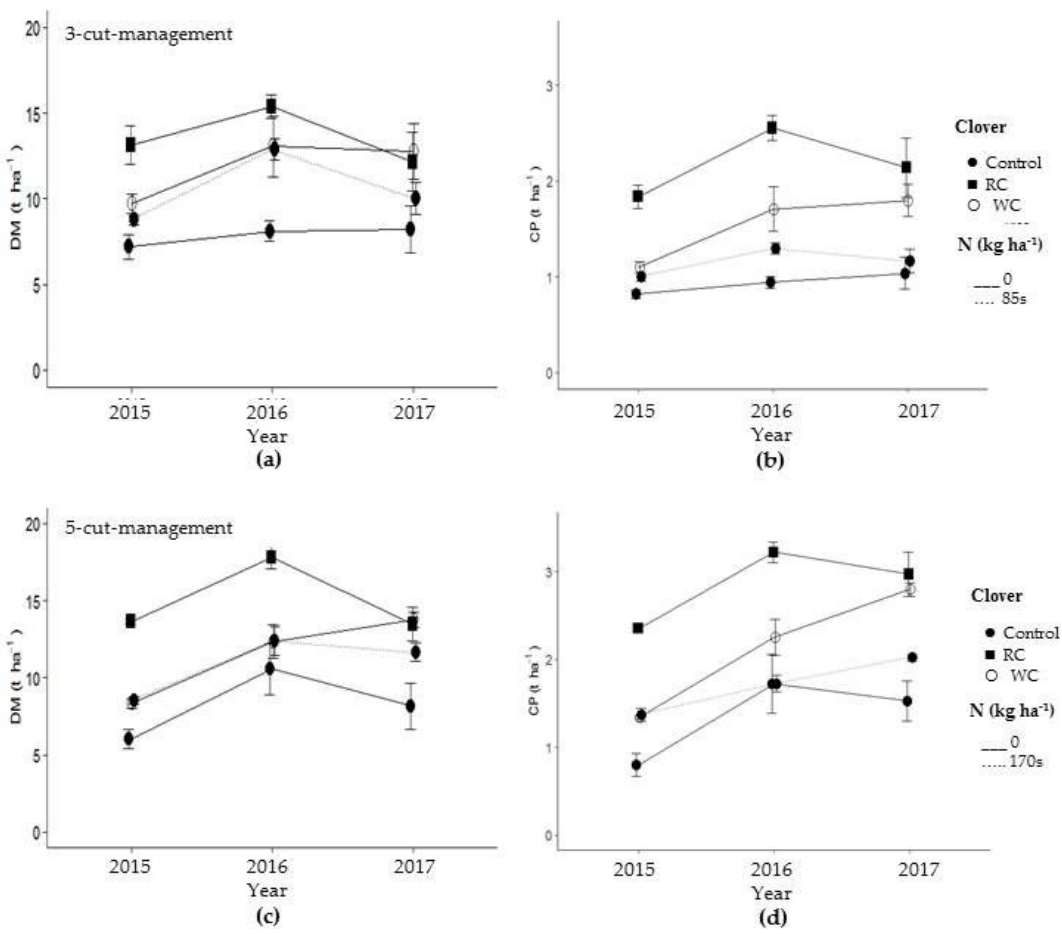

Figure 6. Effect of nitrogen $(\mathrm{N})$ fertilizer application compared to clover reseeding (without additional $\mathrm{N}, \mathrm{RC}-0 \mathrm{~N}, \mathrm{WC}-0 \mathrm{~N})$ on yield attributes under $(\mathbf{a}, \mathbf{b})$ a 3-cut management $\left(0-85 \mathrm{~kg} \mathrm{~N} \mathrm{ha}^{-1}\right)$ and under $(\mathbf{c}, \mathbf{d})$ a 5 cut management $\left(0-170 \mathrm{~kg} \mathrm{~N} \mathrm{ha}^{-1}\right)$. Figure $(\mathbf{a}, \mathbf{c})$ show dry matter yield (DM), and figure $(\mathbf{b}, \mathbf{d})$ show crude protein yield for the three years after reseeding ("s" denotes $\mathrm{N}$ applied as slurry).

Table 3. The sum of dry matter- (DM) and crude protein yield (CP) over three years, as affected by legume reseeding, nitrogen $(\mathrm{N})$ application rate, and cutting frequency.

\begin{tabular}{|c|c|c|c|c|c|c|c|c|}
\hline \multirow{2}{*}{$\begin{array}{c}\text { Leg.- } \\
\text { Treatment }\end{array}$} & & \multicolumn{7}{|c|}{ N Fertilizer Rate $\left(\mathrm{kg} \mathrm{N} \mathrm{ha}^{-1}\right)^{1,2,3}$} \\
\hline & & 0 & 42 & 85 & & 0 & 85 & 170 \\
\hline & & \multicolumn{3}{|c|}{ 3-cut management } & \multicolumn{4}{|c|}{ 5-cut management } \\
\hline & & \multicolumn{7}{|c|}{ DM $\left(\mathrm{t} \mathrm{ha}^{-1} 3\right.$ years $\left.^{-1}\right)$} \\
\hline Control & A & $23.5^{\mathrm{a}}$ & $23.5^{\mathrm{a}}$ & $30.7^{\mathrm{b}}$ & A & $24.7^{\mathrm{a}}$ & $27.9^{\mathrm{a}, \mathrm{b}}$ & $31.8^{\mathrm{b}}$ \\
\hline $\mathrm{RC}$ & $\mathrm{C}$ & 40.7 & 40.6 & 38.5 & $\mathrm{C}$ & 44.9 & 45.1 & 43.8 \\
\hline \multirow[t]{2}{*}{ WC } & B & $35.5^{b}$ & $29.3^{\mathrm{a}}$ & $29.8^{\mathrm{a}}$ & $\mathrm{B}$ & 34.4 & 36.3 & 36.9 \\
\hline & & \multicolumn{7}{|c|}{$\mathrm{CP}\left(\mathrm{t} \mathrm{ha} \mathrm{a}^{-1} 3\right.$ years $\left.^{-1}\right)$} \\
\hline Control & A & $2.8^{\mathrm{a}}$ & $2.94^{\mathrm{a}}$ & $3.40^{\mathrm{b}}$ & $\mathrm{A}$ & $4.05^{\mathrm{a}}$ & $4.47^{\mathrm{a}, \mathrm{b}}$ & $5.16^{b}$ \\
\hline $\mathrm{RC}$ & $\mathrm{C}$ & 6.53 & 6.39 & 5.87 & $\mathrm{C}$ & 8.55 & 8.6 & 8.21 \\
\hline WC & $\mathrm{B}$ & 4.6 & 3.78 & 4.04 & $\mathrm{~B}$ & 6.38 & 6.87 & 6.49 \\
\hline
\end{tabular}

\subsubsection{Protein Yield in Relation to Legume Percentage}

Red clover and WC reseeded plots differed in legume proportion in the sward, with the former achieving generally higher proportions in our trials than the latter. To see, if the effect of legume percentage on protein yield is similar for both legume types, we plotted protein yield in relation to legume percentage for the three years (Figure 7). Data from the five-cut management and only from harvest 1,2 , and 3 are included because harvest $1-3$ contributed most to the total $\mathrm{CP}$-yield $(>75 \%)$. The relationship between legume percentage and $\mathrm{CP}$-yield differed between the three years. In the first year, there was no obvious relation between legume percentage and $\mathrm{CP}$-yield. In the second year (2016), the CP-yield was positively correlated with legume percentage for both RC and WC. In the third year (2017), there was still a correlation between legume percentage and CP-yield, but the correlation 
coefficient was strongly dependent on whether data from control plots were included or excluded. The model based on data from WC and RC reseeded plots only, showed a considerably lower slope (influence of legume percentage) and a lower correlation coefficient. Thus, in the third year an increase in legume percentage had a weak influence on CP-yield of RC- and WC-reseeded plots. However, clover reseeding as such had a strong positive influence on $\mathrm{CP}$-yield when compared to control plots.

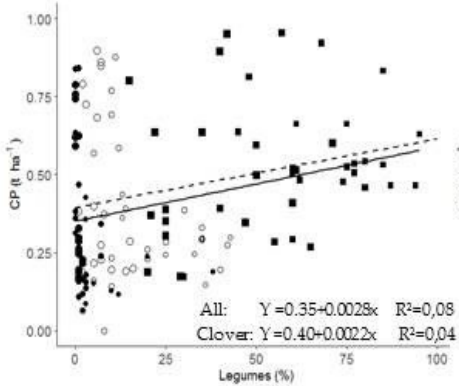

(a)

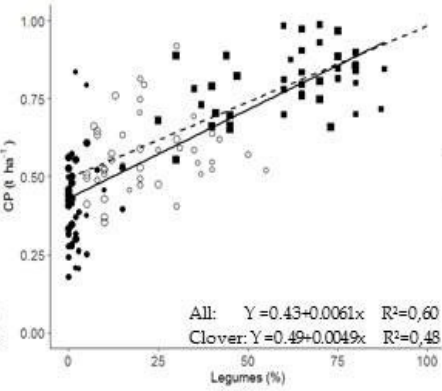

(b)

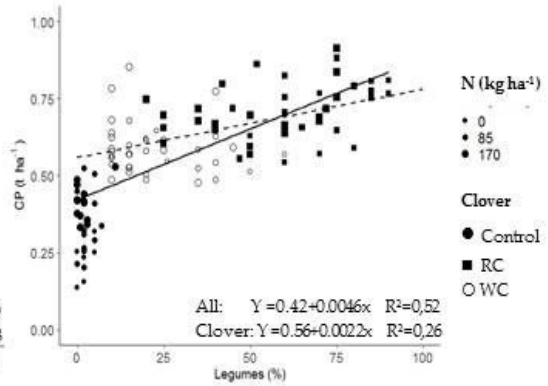

(c)

Figure 7. Legume percentage and their correlation to crude protein yield (CP) in control, red clover (RC) and white clover (WC) reseeded plots, with data from the five-cut management, harvest 1, 2, and 3 in (a) 2015, (b) 2016 and (c) 2017. Data from slurry and mineral-N treated plots are included. (Correlation models: Linear model using all data ("All"), (Control, RC, WC); Linear model using data from clover-reseeded plots only ("Clover"). (RC, WC).

\section{Discussion}

Our study has shown that reseeding of legumes effectively increases the legume proportion in an existing grassland sward for about three years. Achieved legume percentage was dependent on legume type with RC reaching percentages of up to 85 and generally about $75 \%$ and WC reaching percentages of up to $50 \%$ and generally around $35 \%$ under low nitrogen conditions and frequent cutting. Results are in agreement with previous studies, which also reported similarly high percentages of RC after reseeding using similar sowing rates $[18,19,28]$. However, WC was not established successfully in those trials, where $\mathrm{N}$-rates of 120 to $240 \mathrm{~kg} \mathrm{~N} \mathrm{ha}^{-1} \mathrm{a}^{-1}$ were applied. It was suspected that elevated rates of $\mathrm{N}$-fertilizer did impede WC establishment, despite pasture recommended N-rates being applied [29].

Successful establishment of clover seedlings into permanent grassland depends on a number of factors and their interactions. For example, [30] points out a large influence of cutting frequency, stubble height and its interaction with $\mathrm{P}$ and $\mathrm{K}$ nutrition. Indeed, $\mathrm{P}$ nutrition in trials with failed WC establishment [19] was lower than in our current study (current trial: $\mathrm{P}_{\mathrm{CAL}}$ extract $20.3 \mathrm{mg} \mathrm{P}_{2} \mathrm{O}_{5}$ $100 \mathrm{~g}^{-1}$, failed WC trial: $11 \mathrm{mg} \mathrm{P}_{2} \mathrm{O}_{5} 100 \mathrm{~g}^{-1}$ ). However, surrounding the failed WC trial, the sward showed increasing WC over time. The major difference between the trial site and the surrounding site was the amount of $\mathrm{N}$ applied. This circumstantial evidence led us to the conclusion that, in our trials with soils of medium $\mathrm{P}$ nutrition, the $\mathrm{N}$ nutrition is the crucial factor during establishment.

Increasing rates of $\mathrm{N}$ applied in the current trial have shown that the amount of legume established in swards is negatively correlated with N-rates even down to rates as low as $85 \mathrm{~kg} \mathrm{~N}^{-1}$. This reducing effect was observed for both legume species, WC and RC. Only very low rates of $42 \mathrm{~kg} \mathrm{~N} \mathrm{ha}^{-1} \mathrm{did}$ not decrease legume percentages any further. A number of previous studies have shown a negative impact of N-fertilizer on legume proportions [24,31,32], but critical N-rates with no effect on legume percentages varied considerably between those studies. Whereas previous studies [24] suggested that $100 \mathrm{~kg} \mathrm{~N} \mathrm{ha}^{-1}$ are without negative impact on clover proportion, our study suggests that $\mathrm{N}$ rates of $85 \mathrm{~kg} \mathrm{ha}^{-1}$ and possibly lower impede legume proportions. However, when DM- and CP-yield are used as an indicator, then mixed swards were generally not negatively affected by $\mathrm{N}$-fertilizer application rates up to $170 \mathrm{~kg} \mathrm{~N} \mathrm{ha}^{-1}$. The only exception was WC under a low cutting regime, considered unfavorable for WC [20]. These results were similar irrespective of whether slurry or mineral $\mathrm{N}$-fertilizer were used for $\mathrm{N}$-application. 
The DM- and CP-yield was significantly increased by legume reseeding compared to non-legume plots. However, additional $\mathrm{N}$-application did not translate into additional yield in legume reseeded plots, whereas this was the case in control plots. The application of N-fertilizer may just have altered the source of $\mathrm{N}$, which legumes used for growth. A number of studies have shown that $\mathrm{N}$-fertilizer application decreases the average proportion of clover- $\mathrm{N}$ derived from $\mathrm{N}_{2}$-fixation $[11,23]$ in favor of mineral-N. The equal yield of $\mathrm{N}$-fertilized legume plots compared to legume plots without $\mathrm{N}$ in our study suggest that there is a comparable amount of $\mathrm{N}$ in both systems to support equal growth and $\mathrm{N}_{2}$ fixation likely was decreased when medium or high $\mathrm{N}$-fertilizer rates were applied. A rough but valuable model to estimate $\mathrm{N}_{2}$-fixation of $\mathrm{WC}$ and $\mathrm{RC}$ was suggested by [8]. Using our data in their model the $\mathrm{N}_{2}$-fixation of mixed swards with WC or RC can be estimated to be on average 133 and $299 \mathrm{~kg} \mathrm{~N} \mathrm{ha}^{-1} \mathrm{a}^{-1}$ over three years (five-cut: RC: $15 \mathrm{t} \mathrm{ha}^{-1} \mathrm{DM}, 75 \%$ clover; RC: $11.7 \mathrm{t} \mathrm{ha} \mathrm{a}^{-1}$ $\mathrm{DM}, 30 \%$ clover). Estimated amounts are indeed comparable to the mineral $\mathrm{N}$-fertilizer rates applied. The high DM and CP yield achieved in our trials due to legume reseeding and the lack of yield response following $\mathrm{N}$ additions in those plots suggests that additional $\mathrm{N}$-fertilizer applications are not necessary and can be omitted.

Legume reseeded plots had an improved DM-yield compared to grass-dominated control plots without N, and RC-reseeded plots also had an improved DM-yield compared to control plots plus $\mathrm{N}$. Observed yield increases may partly be based on the increase in species diversity, since it was reported that particularly the mix of legumes with grasses caused significant yield increases beyond the level achieved in species-poor communities $[14,33]$. This could also have been a further factor contributing to yield increases in our study. However, nitrogen fixation may still be a crucial factor for yield increases since the below-ground N-pool accumulated by legumes can be $40 \%$ of the aboveground clover-N [34]. This sizable N-pool and possibly N-transfer of fixed-N from legumes to grasses [11,12] likely supports the growth of grass over time.

Making use of the $\mathrm{N}_{2}$ fixation potential of legumes instead of using fossil fuel-dependent $\mathrm{N}$-fertilizer would make sense today. Still, there may be some farm-related constraints that would enforce slurry applications irrespective of losing one of the crucial advantages of legumes, such as $\mathrm{N}_{2}$-fixation. Legumes still have the advantage of having a comparably high content of easily digestible protein, which makes them an important source of protein in grassland-based livestock production [35].

The reseeding of legumes translated into a considerable protein yield increase compared to the control plots which was even more pronounced than DM-yield increases. Comparable protein yield increases were not achieved with $\mathrm{N}$-fertilizer rates up to $170 \mathrm{~kg} \mathrm{~N} \mathrm{ha}^{-1}$, the highest average slurry $\mathrm{N}$-application rate that is today permitted by the revised German fertilization ordinance [36,37]. In our study, the protein yield in the control plots, summarized over three years, was increased from 4.1 to $5.2 \mathrm{t} \mathrm{CP} \mathrm{ha}^{-1} 3$-years ${ }^{-1}$ due to $\mathrm{N}$-fertilizer application $\left(170 \mathrm{~kg} \mathrm{Nha}^{-1} 5\right.$-cut management). In comparison

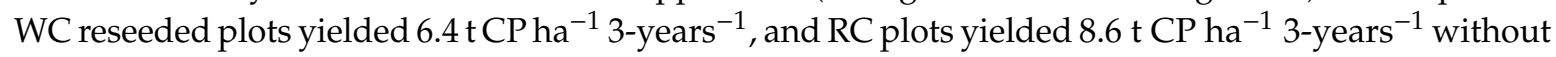
$\mathrm{N}$-fertilizer application (Table 3). With few exceptions, legume reseeded plots achieved a considerable higher protein yield in all three years and under both cutting frequencies, compared to the control plots receiving the highest $\mathrm{N}$-application rate. This shows the protein production or protein yield per hectare can effectively and significantly be increased by introducing legumes into the sward, thus enhancing locally produced protein-rich feedstock.

Yield attributes (DM, CP) were always highest after RC reseeding, generally intermediate after WC reseeding or control-high N plots and lowest in the control-0N. Results would imply that RC is the preferred legume for reseeding in swards. However, yield attributes of $\mathrm{RC}$ reseeded plots increased up to year 2 but already decreased in year 3, whereas for WC plots the yield increased up to year 3 and possibly beyond, under suitable conditions (five-cut management). Similar observations were reported by [31,38], where DM-yield of RC containing plots declined over time whereas DM-yield of WC containing swards remained elevated. The reason for the yield decline may be that RC is considered to be a short-term crop with a lifespan of about three years [39] probably due to its reliance on a taproot system that rarely survives longer than three or four years [20]. During our study, the RC 
plots still showed a superior yield in year 3 compared to the control-high $\mathrm{N}$ plots. This may partly be due to the fact, that we used "Mattenklee" varieties, which are considered to be more persistent than other RC varieties [40]. However, declining RC proportions in the sward by the end of year 3 and start of year 4 already indicate the retreat of $\mathrm{RC}$, and future yield decline appears possible. In comparison, WC reseeded plots did not show a yield decline. Instead, they show a yield increase over time while the legume content remained on an elevated percentage. Nevertheless, RC persistence in our trials was remarkable and results have shown that RC is also usable under a five-cut management.

It is notable that achieved legume percentages after RC or WC reseeding are vastly different (about 75\% RC, about 35\% WC, 0N treatments), whereas CP-yield did not differ nearly to the same extent, particularly in years 2 and 3 . When comparing the relation between clover content and crude protein yield for RC and WC (Figure 7), it becomes obvious that this relationship was not stable over the three years. During the first year after reseeding, no tight relationship between clover content and protein yield was obvious for both species. In contrast, in year 2, the protein yield correlated well to legume percentage for both clover species. In year 3, there was still a significant correlation, but the slope of the model was considerably lower, particularly when only data from legume-reseeded plots were considered. The high amount of $\mathrm{CP}$-yield in legume-containing swards was only weakly related to an increase in legume percentage. These results imply that it is difficult to establish a relationship between legume percentage and crude protein yield, since our results suggest that this depends on the phase of establishment of plants (year 1-3). This may partly be the reason why other studies found it difficult to establish such a relationship [31]. Furthermore, these results imply that a considerably lower percentage of WC (year 3) is sufficient to gain the same amount of crude protein compared to $\mathrm{RC}$, which is in accordance with previous findings [31] and may be based on the higher $\mathrm{N}_{2}$-fixation rate per ha of WC compared to RC [8]. Nevertheless, our data shows that clover percentage can be a reasonable indicator of protein yield, if the phase of establishment of clover plants is known.

\section{Conclusions}

In summary, the benefits of legume reseeding can be considerable, both in terms of an increased DMand $\mathrm{CP}$-yield and also in terms of lowering the necessary $\mathrm{N}$-input to the sward. In particular, $\mathrm{CP}$-yield could be increased beyond the level achieved by mineral fertilizer application up to $170 \mathrm{~kg} \mathrm{~N} \mathrm{ha}^{-1}$. These benefits remained significant over the observed three years and in some cases possibly beyond. Generally, the success of reseeding depends on the competition of the existing grassland sward.

For successful reseeding of legumes, $\mathrm{N}$-rates need to be chosen appropriately and should remain at least below $85 \mathrm{~kg} \mathrm{~N} \mathrm{ha}^{-1}$ to allow best legume establishment. The type of $\mathrm{N}$-fertilizer, mineral or slurry, was shown to be less important and had only a small effect in the first year after reseeding. White clover seems to be somewhat more sensitive to high N-rates than RC.

Additional $\mathrm{N}$-fertilizer applications to legume reseeded plots, whether as organic or mineral $\mathrm{N}$-fertilizer, did not translate into additional DM- or CP-yield and thus can be omitted.

The introduction of legumes into swards increased CP-yield considerably and enables an increase in locally grown protein rich fodder. The relationship between legume percentage and CP-yield varied and was tight only in year 2 after establishment. Nevertheless, the introduction of legumes ensures an increase in CP yield, even though the relationship between clover percentage and CP-yield is not straightforward.

Red clover-reseeded plots yielded the highest amount of DM and CP over three years, whereas the yield of WC reseeded plots was intermediate between RC and control plots. The choice of a suitable clover species needs to take into account cutting frequencies. For low cutting frequencies, only RC can be recommended. For high cutting frequencies, both legume types can be chosen, while their advantages differ somewhat. Red clover is highly productive but can be considered short-term (three years) while WC is more persistent but slightly less productive. The choice depends on farm management options. For $\mathrm{RC}$, it is questionable whether the sward remains productive after the strongly competitive RC retreats quickly in year 4. Most likely, the sward needs to be reseeded again 
after three or four years to sustain productivity and combat intruding weeds. In contast, reseeded white clover was more persistent under high cutting frequencies, so additional reseeding after three year appears not necessary.

Author Contributions: M.E. and U.T. conducted the conceptualization and planned the methodology. M.E. was responsible for project implementation, administration, and funding acquisition. K.W. conducted the formal analysis of the data and wrote the original draft preparation. The review and editing were conducted by all three authors.

Funding: This research was funded by the by the federal state government of Baden-Württemberg grant number [0369E].

Acknowledgments: The authors would like to thank L. Heine and S. Engel for their intense input in the early part of this research project, including setting up the trial, harvesting and sampling. We would also like to thank the field-staff of LAZBW-division of "Grünland," the staff of the LAZBW laboratory, as well as the staff of the LTZ laboratories in Karlsruhe for their reliable work in analyzing the samples. We would like to thank the LAZBW for providing general facilities and the field site.

Conflicts of Interest: The authors declare no conflict of interest. The funders had no role in the design of the study; in the collection, analyses, or interpretation of data; in the writing of the manuscript, or in the decision to publish the results.

\section{References}

1. Tilman, D.; Cassman, K.G.; Matson, P.A.; Naylor, R.; Polasky, S. Agricultural sustainability and intensive production practices. Nature 2002, 418, 671-677. [CrossRef] [PubMed]

2. Godfray, H.C.J.; Beddington, J.R.; Crute, I.R.; Haddad, L.; Lawrence, D.; Muir, J.F.; Pretty, J.; Robinson, S.; Thomas, S.M.; Toulmin, C. Food security: the challenge of feeding 9 billion people. Science 2010, 327, 812-818. [CrossRef] [PubMed]

3. Woods, J.; Williams, A.; Hughes, J.K.; Black, M.; Murphy, R. Energy and the food system. Philos. Trans. R. Soc. Br. 2010, 365, 2991-3006. [CrossRef] [PubMed]

4. Snyder, C.S.; Bruulsema, T.W.; Jensen, T.L.; Fixen, P.E. Review of greenhouse gas emissions from crop production systems and fertilizer management effects. Agric. Ecosyst. Environ. 2009, 133, 247-266. [CrossRef]

5. IPCC. Guidelines for National Greenhouse Gas Inventories; IPCC: Kyoto, Japan, 2006; Available online: www. ipcc-nggip.iges.or.jp/public/index.html (accessed on 15 February 2019).

6. Cassman, K.G.; Dobermann, A.; Walters, D.T. Agroecosystems, nitrogen-use efficiency, and nitrogen management. Ambio 2002, 31, 132-140. [CrossRef] [PubMed]

7. Hugenin-Eli, O.; Delaby, L.; Le Clećh, S.; Moreno, G.M.; Teixeira, R.F.M.; Schneider, M.K. Optimizing ecosystem services provided by grassland systems. Grassl. Sci. Eur. 2018, 23, 520-534.

8. Carlsson, G.; Huss-Danell, K. Nitrogen fixation in perennial forage legumes in the field. Plant Soil 2003, 253, 353-372. [CrossRef]

9. Rochette, P.; Janzen, H.H. Towards a revised coefficient for estimating $\mathrm{N}_{2} \mathrm{O}$ emissions from legumes. Nutr. Cycl. Agroecosyst. 2005, 73, 171-179. [CrossRef]

10. Barton, L.; Butterbach-Bahl, K.; Kiese, R.; Murphy, D.V. Nitrous oxide emissions from a cropped soil in a semi-arid climate. Glob. Chang. Biol. 2011, 17, 1153-1166. [CrossRef]

11. Boller, B.C.; Nösberger, J. Symbiotically fixed nitrogen from field-grown white and red clover mixed with ryegrasses at low levels of 15N-fertilization. Plant Soil 1987, 104, 219-226. [CrossRef]

12. Zanetti, S.; Hartwig, U.A.; Lüscher, A.; Hebeisen, T.; Frehner, M.; Fischer, B.U.; Hendrey, G.R.; Blum, H.; Nösberger, J. Stimulation of symbiotic $\mathrm{N}_{2}$ fixation in Trifolium repens L. under elevated athmospheric $\mathrm{pCO}_{2}$ in a grassland ecosystem. Plant Physiol. 1997, 112, 575-583. [CrossRef] [PubMed]

13. Pirhofer-Walzl, K.; Rasmussen, J.; Hogh-Jensen, H.; Eriksen, J.; Soegaard, K.; Rasmussen, J. Nitrogen transfer from forage legumes to nine neighboring plants in a multi-species grassland. Plant Soil 2012, 350, 71-84. [CrossRef]

14. Nyfeler, D.; Huguenin-Elie, O.; Suter, M.; Frossard, E.; Connolly, J.; Lüscher, A. Strong mixture effects among four species in fertilized agricultural grassland led to persistent and consistent transgressive overyielding. J. Appl. Ecol. 2009, 46, 683-691. [CrossRef] 
15. Rochon, J.J.; Doyle, C.J.; Greef, J.M.; Hopkins, A.; Molle, G.; Sitzia, M.; Scholefield, D.; Smith, C.J. Grazing legumes in Europe: a review of their status, management, benefits, research needs and future prospects. Grass Forage Sci. 2004, 59, 197-214. [CrossRef]

16. Guckert, A.; Hay, R.K.M. The overwintering, spring growth and Yield in mixed species swards of white clover in Europe. Ann. Bot. 2001, 88, 667-668. [CrossRef]

17. Suter, M.; Connolly, J.; Finn, J.A.; Loges, R.; Kirwan, L.; Sebastia, M.T.; Lüscher, A. Nitrogen yield advantage from grass-legume mixtures is robust over a wide range of legume proportions and environmental conditions. Glob. Chang. Biol. 2015, 21, 2424-2438. [CrossRef] [PubMed]

18. Elsaesser, M.; Engel, S.; Thumm, U. Effects of legume establishment by slot-seeding on dry matter and protein yield. Grassl. Sci. Eur. 2016, 21, 507-509.

19. Heine, L.; Thumm, U.; Elsaesser, M. Development and persistence of reseeding legumes in permanent grassland under different cutting and fertilization intensity. Grassl. Sci. Eur. 2018, 23, 219-221.

20. Black, A.D.; Laidlaw, A.S.; Moot, D.J.; O'Kiely, P. Comparative growth and management of white and red clovers. Irish J. Agric. Food Res. 2009, 48, 149-166.

21. Frame, J. Forage Legumes for Temperate Grasslands; FAO, and Science Publishers: Rome, Italy; Enfield, CT, USA, 2005.

22. Nyfeler, D.; Huguenin-Elie, O.; Suter, M.; Frossard, E.; Lüscher, A. Grass-legume mixtures can yield more nitrogen than legume pure stands due to mutual stimulation of nitrogen uptake from symbiotic and non-symbiotic sources. Agric. Ecosyst. Environ. 2011, 140, 155-163. [CrossRef]

23. Ledgard, S.F.; Sprosen, M.F.; Penno, J.W.; Rajendram, G.S. Nitrogen fixation by white clover in pastures grazed by dairy cows: Temporal variation and effects of nitrogen fertilization. Plant Soil 2001, 229, 177-187. [CrossRef]

24. Trott, H.; Wachendorf, M.; Ingwersen, B.; Taube, F. Performance and environmental effects of forage production on sandy soils. I. Impact of defoliation system and nitrogen input on performance and $\mathrm{N}$ balance of grassland. Grass Forage Sci. 2004, 59, 41-55. [CrossRef]

25. Klapp, E.; Stählin, A. Standorte, Pflanzengesellschaften und Leistung des Grünlandes. 122 Seiten. Verlag Eugen Ulmer, Stuttgart-S. 1936. Z. Pflanzenernaehr. Dueng. Bodenk. 1936, 43, 221-222.

26. Geiger, G. Überarbeitete Neuausgabe von Geiger, R.: Koppen-Geiger/Klima der Erde; Wandkarte 1:16 Mill.; Klett-Perthes: Gotha, Germany, 1961.

27. VDLUFA. Methodenbuch III 31.2; VDLUFA: Darmstadt, Germany, 2004.

28. Elsaesser, M.; Engel, S.; Breunig, J.; Thumm, U. Increasing protein yields from grassland by reseeding of legumes. Grassl. Sci. Eur. 2014, 19, 880-883.

29. Elsaesser, M. Merkblätter für die Umweltgerechte Landwirtschaft; Landwirtschaftliches Zentrum Baden-Württemberg: Aulendorf, Germany, 2008.

30. Tracy, B.F.; Schlueter, D.H.; Flores, J.P. Conditions that favor clover establishment in permanent grass swards. Grassl. Sci. 2014, 61, 34-40. [CrossRef]

31. Eriksen, J.; Askegaard, M.; Soegaard, K. Complementary effects of red clover inclusion in ryegrass-white clover swards for grazing and cutting. Grass Forage Sci. 2014, 69, 241-250. [CrossRef]

32. Klöcker, W. The yield potential of white clover-its contribution to yield performance of newly established permanent pasture. 3. Borler site in the Eifel region. Das wirtschaftseigene Futter 1989, 35, 67-78.

33. Finn, J.A.; Kirwan, L.; Connolly, J.; Sebastaia, M.T.; Helgadottir, A.; Baadshaug, O.H.; Belanger, G.; Black, A.; Brophy, C.; Collins, R.P.; et al. Ecosystem function enhanced by combining four functional types of plant species in intensively managed grassland mixtures: a 3-year continental scale field eCPeriment. J. Appl. Ecol. 2013, 50, 365-375. [CrossRef]

34. Hammelehle, A.; Oberson, A.; Lüscher, A.; Mäder, P.; Mayer, J. Above- and belowground nitrogen distribution of a red clover-perennial ryegrass sward along a soil nutrient availability gradient established by organic and conventional cropping systems. Plant Soil 2018, 425, 507-525. [CrossRef]

35. Lüscher, A.; Mueller-Harvey, I.; Soussana, J.F.; Rees, R.M.; Peyraud, J.L. Potential of legume-based grassland-livestock systems in Europe: a review. Grass Forage Sci. 2014, 69, 206-228. [CrossRef]

36. Elsaesser, M.; Messner, J. Düngung von Wiesen, Weiden und Feldfutter. In Merkblätter für die Umweltgerechte Landwirtschaft; Landwirtschaftliches Zentrum Baden-Württemberg: Aulendorf, Germany, 2018. 
37. Mokry, M.; Mann, T.; Seiter, C.; Heckelmann, A.; Messner, J.; Elsäßer, M. Düngeverordnung. In Merkblätter für die Umweltgerechte Landwirtschaft; Landwirtschaftliches Zentrum Baden-Württemberg: Aulendorf, Germany, 2018.

38. Frankow-Lindberg, B.E.; Halling, M.; Höglind, M.; Forkman, J. Yield and stability of yield of single- and multi-clover grass-clover swards in two contrasting temperate environments. Grass Forage Sci. 2009, 64, 236-245. [CrossRef]

39. Conaghan, P. Breeding red clover (Trifolium pratense L.) for improved yield and persistence. Grassl. Sci. 2018, 23, 139-141.

40. Hoekstra, N.J.; De Deyn, G.B.; van Eekeren, N. Red clover cultivars of Mattenklee type show higher yield and persistence than Ackerklee type. Grassl. Sci. Eur. 2018, 23, 66-68.

(C) 2019 by the authors. Licensee MDPI, Basel, Switzerland. This article is an open access article distributed under the terms and conditions of the Creative Commons Attribution (CC BY) license (http://creativecommons.org/licenses/by/4.0/). 